\title{
Purification and characterization of novel fibrinolytic proteases as potential antithrombotic agents from earthworm Perionyx excavatus
}

\author{
Tram Thi Bich Phan ${ }^{1}$, Tien Duy Ta ${ }^{2 *}$, Dung Thi Xuan Nguyen ${ }^{3}$, Lambertus AM Van Den Broek ${ }^{4}$ and \\ Giang Thi Huong Duong ${ }^{3}$
}

\begin{abstract}
Six protease fractions, namely FI, FII, FIII-1, FIII-2, FIII-3 and FIV, were isolated from Perionyx excavatus earthworm biomass by acetone precipitation, followed by serial chromatography using anion exchange, hydrophobic interaction and size exclusion chromatography. All fractions exhibited strong hydrolytic activity towards casein. The activity of six fractions towards fibrin, determined by fibrin plate assay, ranged from 44 to 831 plasmin unit.mg ${ }^{-1}$ and ranked as Flll$3>$ FIII-2 $>$ FI $>$ FIII-1 $>$ FIV $>$ FII. Casein degradation was optimal at pH 7 and 11, and at 45-60 ${ }^{\circ}$. All fractions were considerably stable at high temperature and wide $\mathrm{pH}$ range. They were completely inhibited by phenylmethylsulfonyl fluoride (PMSF). The molecular weights (MW) and isoelectric points (pl) determined by 2D-electrophoresis were 27.5-34.5 kDa, and 4.3-5.2, respectively. Tandem mass spectrometry (MS) analysis was used to deduce the amino acid sequences of some peptides from FIII-1 and FIII-2. The sequences shared 16.9\% and 13.2\% similarity, respectively, with the fibrinolytic enzymes from two related earthworm species, Lumbricus rubellus and Eisenia fetida. The $P$. excavatus proteases were classified as serine proteases. They could perform rapid hydrolysis on both coagulated fibrous fibrin and soluble fibrinogen monomers without the presence of activators such as tPA or urokinase.
\end{abstract}

Keywords: chromatography, fibrinolysis, Perionyx excavatus, PMSF, serine protease, tandem MS analysis

\section{Introduction}

Cardiovascular diseases have become one of the biggest concerns all over the world (Grundy et al. 1999). Among these, thrombosis is the most widespread within the elderly population. The disease results from severe blood-clotting, which leads to obstruction of the blood flow circulation. In the physiological state, fibrin and platelets are utilized for clotting to prevent blood loss from injuries in a process called hemostasis (Furie and Furie 2008). A serine protease called plasmin acts to digest blood clots via fibrinolysis to properly terminate the hemostasis. Plasmin deficiency is one reason that leads to thrombosis due to insufficient clots degradation.

Fibrin is a fibrous polymer protein that plays an important role in the final blood coagulation step in

\footnotetext{
* Correspondence: tienta2512@dhtcct.edu.vn

${ }^{2}$ Faculty of Food Processing Technology, Can Tho University of Technology, Can Tho, Vietnam

Full list of author information is available at the end of the article
}

hemostasis. The fibrinogen monomer is a $304 \mathrm{kDa}$ glycoprotein containing two sets of three different chains: $A \alpha, B \beta$ and $\gamma$ (Mosesson 2005). The conversion of fibrinogen into fibrin requires the presence of thrombin, a serine protease that cleaves the $\mathrm{N}$-terminus of $\mathrm{A} \alpha$ and B $\beta$ chain (Mosesson et al. 2001). Fibrinogen level was reported to be significantly related to the incidence of cardiovascular disease in both men and women during the tenth biennial examination of the Framingham Study (Kannel et al. 1987). Treatment of cerebral venous thrombosis currently relies on the use of anticoagulants such as heparin, which is also a medicament for deep vein thrombosis (Stam et al. 2003) despite the risk of consequent occurrence of intracranial hemorrhage (Einhaupl et al. 1991 and Mehraein et al. 2003). Enzyme therapy of thrombosis has been investigated since 1969 by using streptokinase, a fibrinolytic enzyme (Kakkar et al. 1969), and was reported to be a better treatment 
for acute deep vein thrombosis than of heparin (Marder et al. 1977 and Arnesen et al. 1982).

A novel fibrinolytic enzyme, namely lumbrokinase, has been isolated from some earthworm species such as Lumbricus rubellus (Cho et al. 2004; Mihara et al. 1991 and Nakajima et al. 1983) and Eisenia fetida (Yang and Ru 1997), and was thoroughly characterized. They have been identified as serine protease isozymes, which are highly thermostable and alkali tolerant. The genes encoding strong fibrinolytic enzymes from these earthworms have been identified (Dong et al. 2004). High-throughput production of these enzymes by recombinant DNA technology has been conducted in Escherichia coli (Cho et al. 2004 and $\mathrm{Xu}$ et al. 2010) and Pichia pastoris (Ge et al. 2005 and Sugimoto et al. 2005). The recombinant enzymes expressed strong fibrinolytic activity both in vitro (Sugimoto et al. 2005) and in vivo in rats via oral administration (Cho et al. 2004). Crystallographic data of two components of $L$. rubellus lumbrokinase were obtained, revealing the structure determinants of their catalytic mechanisms (Tang et al. 2002 and Wang et al. 2005). The analysis showed that the structure of component $B$ resembled that of the trypsyin-like proteases, and was the first reported glycosylated trypsin-like structure. The study also revealed the structural basis for high stability and complicated post-translational modifications of the enzyme.

Application of the fibrinolytic enzymes has also been of great interest in Vietnam, focusing especially on the use of local enzyme sources. The preliminary experiments of this research have discovered the novel and remarkably strong firbinolytic enzymes from Perionyx excavatus earthworm (family Megascolecidae). This species has been widely cultivated in Southern Vietnam for the production of aquatic animal feeds and compost. In our study, an extensive purification of these proteases was carried out together with the characterization of temperature and $\mathrm{pH}$ optimum, inhibition, substrate specificity, fibrinolytic effect and partial sequencing. We have found the potential of these enzymes as effective fibrinolytic agents. The study was thus aimed to understand more deeply the properties of these enzymes and to initially evaluate their applicability in thrombosis treatment.

\section{Materials and methods Materials}

Living earthworms (P. excavates; 8-9 weeks old) were purchased from the farms in An Giang province, Vietnam. Protease substrates included casein from Merck (USA), fibrinogen (together with thrombin and human plasmin), $N \alpha$-benzoyl-L-arginine $p$-nitroanilide (BApNA), and $N \alpha$-benzoyl-L-tyrosine $p$-nitroanilide (BT $p$ NA) from Sigma-Aldrich (USA). The enzyme inhibitors were bought from Sigma (USA). The 2D-electrophoresis kits were obtained from Bio-Rad (USA).

\section{Autolysis of $P$. excavatus}

Earthworm biomass was washed and finely homogenized in distilled water containing $0.1 \%(\mathrm{w} / \mathrm{v})$ sodium azide. Autolysis was initially performed at $45^{\circ} \mathrm{C}$ for 4 hours and continued at room temperature for 15 days with stirring. Enzyme activity was measured daily by the modified method of Anson (Anson 1938) using casein as substrate. One activity unit (U) was defined as the amount of enzyme that catalyzed the release of $1 \mu \mathrm{mol}$ of tyrosine per minute at $30^{\circ} \mathrm{C}$ at $\mathrm{pH}$ 7.5. Specific activity (expressed in U.mg ${ }^{-1}$ ) was defined as the activity per milligram of total protein, which was determined by the Lowry protein assay (Lowry 1951).

\section{Purification of $P$. excavatus proteases}

The autolysate was centrifuged $(11,200 \times \mathrm{g})$ at $4{ }^{\circ} \mathrm{C}$ for 30 minutes, and the supernatant was precipitated in pre-chilled acetone at $4^{\circ} \mathrm{C}$ for 2 hours. The precipitate was collected by centrifugation $(11,200 \times \mathrm{g})$ at $4^{\circ} \mathrm{C}$ for 30 minutes and was lyophilized. A series of chromatographic techniques were used for purification. Fractions containing proteases were collected and analyzed by SDS-PAGE (Hames 1998) after each purification step.

\section{Anion exchange chromatography (AEX)}

Precipitated protein was re-dissolved in $20 \mathrm{mM}$ Tris$\mathrm{HCl}$ buffer $\mathrm{pH} 8.5$ and was loaded on to a $1.5 \times 40 \mathrm{~cm}$ Unosphere Q (Bio-Rad, USA) column at a flow-rate of $0.8 \mathrm{ml} \cdot \mathrm{min}^{-1}$. Bound proteins were eluted in the same buffer, with a continuous $\mathrm{NaCl}$ gradient from 0 to $0.45 \mathrm{M}$ at a flow-rate of $1 \mathrm{ml} \cdot \mathrm{min}^{-1}$.

\section{Hydrophobic interaction chromatography (HIC)}

Each active fraction was dialyzed against $20 \mathrm{mM}$ Tris- $\mathrm{HCl}$ buffer $\mathrm{pH} 8.5$ for desalting; subsequently $30 \%(\mathrm{w} / \mathrm{v}$ ) ammonium sulfate (AS) was added, followed by loading the sample on to a $1.5 \times 30 \mathrm{~cm}$ Phenyl Sepharose (GE Healthcare, UK) column at a flow-rate of $1 \mathrm{ml} \cdot \mathrm{min}^{-1}$. Elution was done using a continuous AS gradient from $30 \%$ to $0 \%$ at the same flow-rate.

\section{Size exclusion chromatography (SEC)}

SEC was carried out for each active HIC fraction on a Superose 12 column (GE Healthcare, UK) using the Biologic HR System (Bio-Rad, USA). The running buffer was $20 \mathrm{mM}$ Tris- $\mathrm{HCl}$ buffer $\mathrm{pH} 7.5$ containing $15 \mathrm{mM} \mathrm{NaCl}$, passing through the column at a flow-rate of $0.5 \mathrm{ml} . \mathrm{min}^{-1}$. Eluted fractions were dialyzed against water and freezedried using a VirTis Bench Top Manifold Freeze Dryer (SP Scientific, USA) and stored at $-20^{\circ} \mathrm{C}$ for later use.

\section{Characterization of $P$. excavatus protease fractions Determination of optimal temperature and thermostability}

The caseinolytic assay was performed to determine the optimal temperature for each active SEC fraction in $50 \mathrm{mM}$ sodium phosphate buffer $\mathrm{pH} 7.5$ at different temperature ranging from $30^{\circ} \mathrm{C}$ to $80^{\circ} \mathrm{C}$ in 10 minutes. 
To investigate the thermal stability, each fraction was incubated at different temperatures between 37 and $70^{\circ} \mathrm{C}$ for 3 hours, and the remaining activity (expressed as $\%$ of the activity at $37^{\circ} \mathrm{C}$ ) was determined after 30,60 , 120 and 180 minutes.

\section{Determination of optimal $\mathrm{pH}$ and $\mathrm{pH}$-tolerance}

Each fraction was assayed for caseinolytic activity at $30^{\circ} \mathrm{C}$ in different $\mathrm{pH}$-buffered solutions from 3 to 12 , prepared as follows: $100 \mathrm{mM}$ Glycine- $\mathrm{HCl}(\mathrm{pH} 2)$, $100 \mathrm{mM}$ citrate-phosphate ( $\mathrm{pH}$ 3-5), $100 \mathrm{mM}$ sodium phosphate (pH 6-8), $100 \mathrm{mM}$ Glycine- $\mathrm{NaOH}$ (pH 9-11), and $\mathrm{KCl}-\mathrm{NaOH}(\mathrm{pH} 12-13)$. The $\mathrm{pH}$ tolerance was determined by incubating each fraction in these buffer solutions for 16 hours at $4^{\circ} \mathrm{C}$; and after neutralization at $30^{\circ} \mathrm{C}$ the remaining activity was determined (expressed as $\%$ of the activity at $\mathrm{pH} 7$ ). In addition, the long-term storage of these enzymes was also investigated using distilled water and $50 \mathrm{mM}$ sodium phosphate buffer $\mathrm{pH} 7.5$ as preservative solvents. The freeze-dried enzymes were dissolved in these solvents containing $0.1 \%(\mathrm{w} / \mathrm{v})$ sodium azide, and stored in carefully-sealed glass vials at $4{ }^{\circ} \mathrm{C}$ for 10 months. The remaining activity, displayed as \% of the initial activity, was determined every month.

\section{Enzyme inhibition assay was done with eight inhibitors}

PMSF, $N$-torsyl-L-phenylalanine chloromethyl ketone (TPCK), aprotinin, leupeptin, soybean trypsin inhibitor (SBTI), ethylene diamine tetraacetic acid (EDTA), chymostatin and peptastatin. The used concentration ranged from 0.01 to $1 \mathrm{mM}$. Samples incubated with casein but without inhibitors were used as controls. Each fraction was incubated separately with each inhibitor in $50 \mathrm{mM}$ sodium phosphate buffer $\mathrm{pH} 7.5$ containing casein at $37^{\circ} \mathrm{C}$ for 10 minutes. The measured activity was compared with the controls.

\section{Hydrolytic assay using different substrates}

The hydrolytic ability towards different substrates such as casein, fibrin, $\mathrm{BA} p \mathrm{NA}$, and $\mathrm{BT} p \mathrm{NA}$ was examined. The assays for the last two substrates were performed at $37^{\circ} \mathrm{C}$ in $50 \mathrm{mM}$ sodium phosphate buffer $\mathrm{pH} 7.5$ based on the method of (Wang et al. 2005). One activity unit (U) on these substrates was defined as the amount of enzyme that released of $1 \mu \mathrm{mol}$ of $p$-nitroaniline under the given conditions. Fibrinolysis was performed on a fibrin plate as described by (Choi and Sa (2001)). Briefly, a mixture of $0.6 \%(\mathrm{w} / \mathrm{v})$ fibrinogen and $2 \%(\mathrm{w} / \mathrm{v})$ agar was prepared in $50 \mathrm{mM}$ sodium phosphate buffer $\mathrm{pH}$ 7.5 , boiled for 2 minutes, cooled down to $55^{\circ} \mathrm{C}$ and subsequently added with thrombin (10 NIH unit.ml ${ }^{-1}$ ) for coagulation in a Petri disc. Ten $\mu$ l of enzyme solution was pipetted into the small holes created on the plate and incubated at $37^{\circ} \mathrm{C}$ for one hour. Fibrinolytic activity, expressed as plasmin unit (PlasminU), was extrapolated from the area of the hydrolytic zones based on a human plasmin standard curve. In vitro cleavage of fibrinogen was investigated by incubating each protease fraction $\left(0.2 \mathrm{mg} \cdot \mathrm{ml}^{-1}\right)$ with bovine fibrinogen $\left(1 \mathrm{mg} \cdot \mathrm{ml}^{-1}\right)$ at $37^{\circ} \mathrm{C}$ in $50 \mathrm{mM}$ sodium phosphate buffer $\mathrm{pH} 7.5$ containing $100 \mathrm{mM} \mathrm{NaCl}$. Aliquots of $10 \mu \mathrm{l}$ were taken out of the reaction mixture after 10, 20, 30, 60, 90, 120, 180, 240 and 480 minutes, and were visualized on SDS-PAGE gel. 2D-electrophoresis-coupled MS/MS sequencing

The protease fractions were purified using a 2D-Cleanup Kit. Isoelectric focusing (IEF) dimension was run on $\mathrm{pH} 3-$ 10 IPG-Strips, and the second dimension was carried out on a $12 \%$ polyacrylamide gel without stacking layer, according to the manufacturer's user manuals. Images were captured by GelDocTM XR+ system (Bio-Rad, USA) and were analyzed using PDQuestTM 2-D Analysis Software (BioRad, USA) for MW and pI calculation. Each protein spot was excised, digested with trypsin, and purified using the protocol from the Protein and Proteomics Centre (NUS, Singapore). Tandem MS analyses for these peptides were carried out at the Laboratory of Protein and Proteomics Centre (NUS, Singapore) using a MALDI-TOF-TOF MS: 4800 Proteomics Analyzer instrument (Applied Biosystems, Framingham, USA).

\section{Results}

\section{Purification of $P$. excavatus proteases}

The hydrolytic activity on casein of the crude extract before autolysis was determined as $0.02{\mathrm{U} . \mathrm{mg}^{-1}}^{-1}$ To examine the further activation of these proteases, earthworm biomass was subjected to autolysis at $45^{\circ} \mathrm{C}$ in 4 hours, following by a 15-day autolysis at room temperature. Consequently, a two-fold increase of caseinolytic activity was achieved after 10 days.

Precipitation of earthworm proteins from the autolysate by acetone was done after the completion of autolysis. The pre-chilled acetone:lysate 2:1 (v/v) ratio resulted in the highest recovery yield of proteins (31\%). Although the yield was not very high, the total proteolytic activity was more or less the same as prior to precipitation (76.84 $\mathrm{U}$ in comparison to $81.05 \mathrm{U})$. The specific proteolytic activity was therefore increased three-fold $\left(0.138 \mathrm{U}_{\mathrm{mg}} \mathrm{m}^{-1}\right.$ in comparison to $0.045 \mathrm{U} \cdot \mathrm{mg}^{-1}$ ).

After desiccation, earthworm proteins were dissolved in $20 \mathrm{mM}$ Tris- $\mathrm{HCl}$ buffer $\mathrm{pH} 8.5$ and subjected to AEX using a Unosphere Q column. Four fractions, namely from FI to FIV, possessing caseinolytic activity were collected when applying a $\mathrm{NaCl}$ gradient of $0-0.45 \mathrm{M}$ (Figure 1). FI had the highest activity. SDS-PAGE profile of all fractions showed impurities (data not shown), thus requiring further purification processes.

Each fraction was loaded onto a phenyl sepharose column after dialysis, and a gradient of $30-0 \%$ AS concentration was used for elution. FI and FII were eluted in single prominent peaks (Figure 2A and $2 \mathrm{~B}$ ). In contrast, FIII was further separated into three fractions, namely 


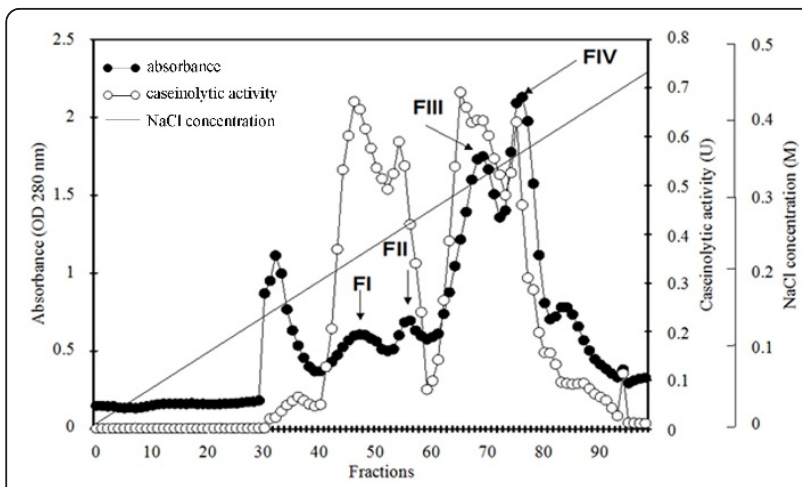

Figure 1 Anion exchange chromatogram of $P$. excavatus crude proteins. Four peaks indicated as Fl, FIl, FIII, and FIV (arrows) with caseinolytic activity were obtained when eluting with a continuous gradient of $\mathrm{NaCl}$ concentration $(0-0.45 \mathrm{M})$.

FIII-1, FIII-2 and FIII-3, having caseinolytic activity (Figure 2C). FIV was fractioned into two partially overlapping peaks; however, only the later one had caseinolytic activity and thus was referred to as FIV (Figure 2D). After this step, FI and FII showed high purity as determined by SDS-PAGE (data not shown). The sub- fractions of FIII and FIV, however, still contained some low MW contaminants (data not shown). Thus a subsequent SEC was necessary to purify these fractions and to confirm the purity of the others as well.

SEC was carried out for all active HIC fractions on a Superose 12 column. Three fractions FI, FII and FIII-1 eluted as a single peak with a MW of 28,29 and $35 \mathrm{kDa}$, respectively. These results were in accordance with those obtained from SDS-PAGE (Figure 3B). The major peak of FIII-2 appeared to be a single band of $34 \mathrm{kDa}$ on SDSPAGE gel and showed protease activity. FIV was fractionated into two peaks but only the large peak of $34 \mathrm{kDa}$ protein (marked as FIV*) showed proteolytic activity (Figure 3A). FIII-3 was also separated into two peaks, namely FIII-3a and FIII-3b, with a MW of 33 and $31 \mathrm{kDa}$, respectively, and only the latter one showed protease activity. Both fractions had a band of $33 \mathrm{kDa}$ on SDS-PAGE gel. Besides, FIII-3b contained also a $31 \mathrm{kDa}$ protein which was not present in FIII-3a, as seen in the SEC chromatogram. Most fractions were more than 98\% pure as estimated by SDS-PAGE Coomassie Brilliant Blue staining. Only FIII-3b contained two proteins with more or less the same intensity. There were six proteolytic

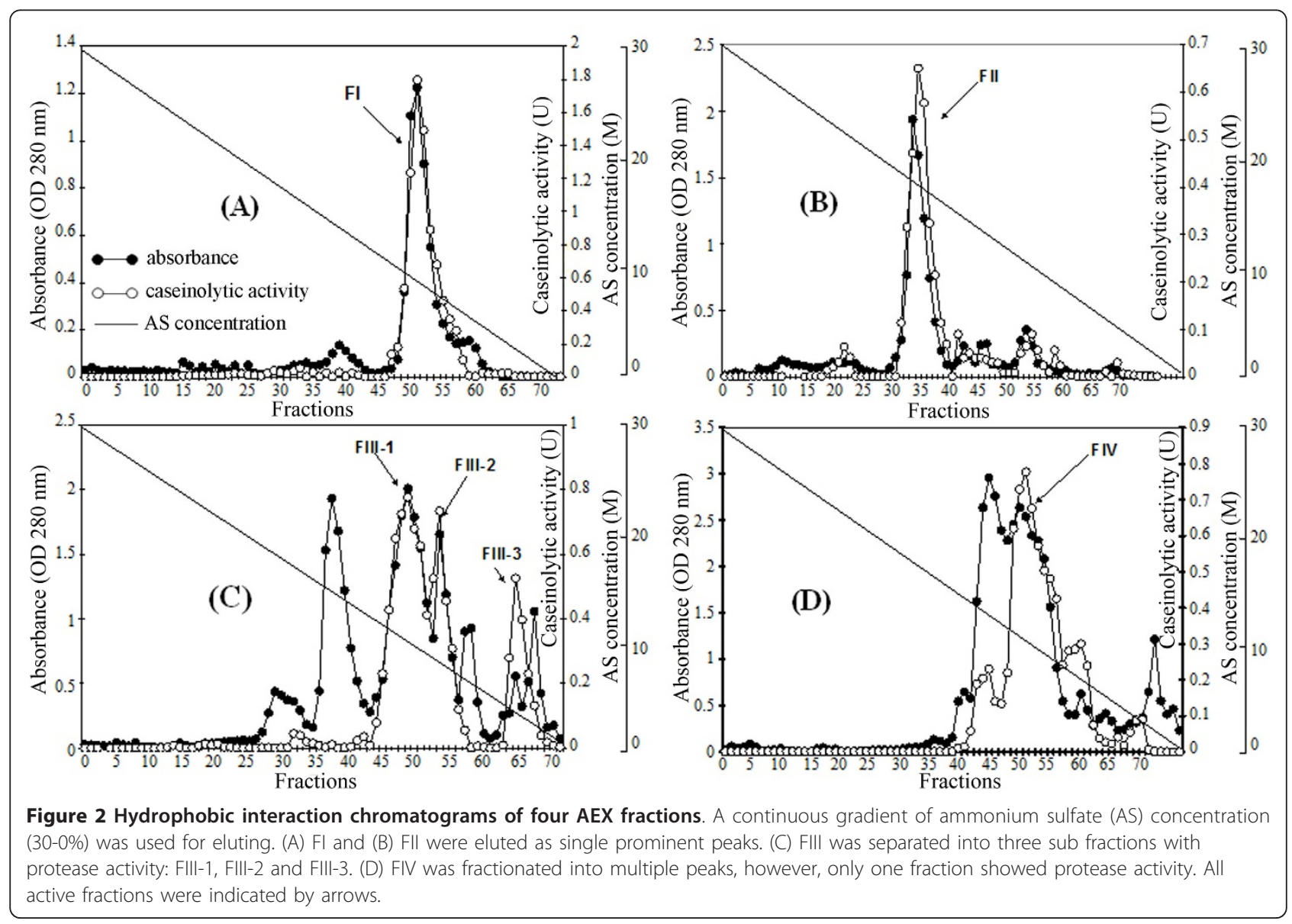



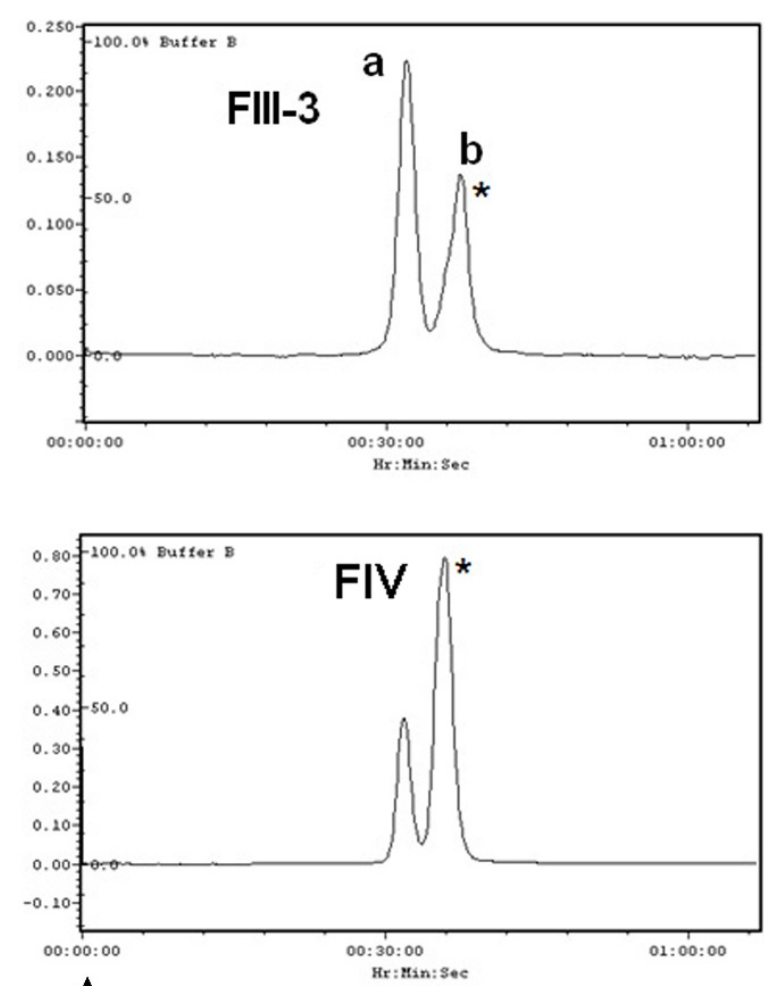

A

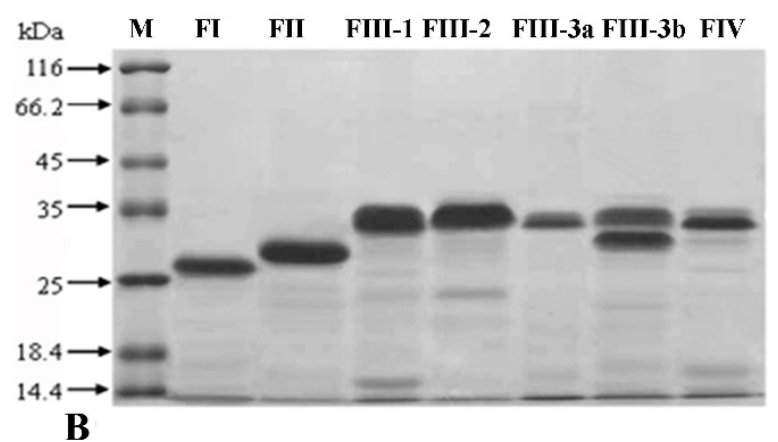

Figure 3 Profiling of $P$. excavatus protease fractions: (A) Size exclusion chromatogram of Fll-3 and FIV presented their fractionation into two peaks, ones of which marked with an asterisk showed protease activity. (B) SDS-PAGE profiling of all SEC fractions.

fractions in total that were purified. The same number of fractions was also reported for $L$. rubellus lumbrokinase using a similar purification strategy (Mihara et al. 1991).

\section{Effect of temperature and $\mathrm{pH}$ on the stability of $P$. excavatus proteases}

All fractions exhibited maximal proteolytic activity in the temperature range of $60-65^{\circ} \mathrm{C}$. Increasing the temperature to $70^{\circ} \mathrm{C}$ caused rapid loss of activity, and between $75-80^{\circ} \mathrm{C}$ almost complete inactivation was observed (Figure 4A). The thermostability over time was examined at different temperatures in a 3-hour period. These proteases were highly stable at temperature below $50^{\circ} \mathrm{C}$ but had rapid activity loss of $10-30 \%$ from $50^{\circ} \mathrm{C}$ onward. Higher temperatures inactivated these enzymes very rapidly. FI and FII were more stable than other fractions, as their activity decrease only about $10-20 \%$ at temperatures from 50 to $60^{\circ} \mathrm{C}$ (Figure 4B).

All proteases expressed optimal activity at both $\mathrm{pH} 7$ and 11, except for FIII-1 which showed the highest activity only at $\mathrm{pH} 7$ (Figure $5 \mathrm{~A}$ ). The proteases of $P$. excavatus were stable in a wide $\mathrm{pH}$ range from 4 to 12 during 16 hours (Figure 5B). Similar results were reported for Korean and Japanese L. rubellus (Cho et al. 2004 and Mihara et al. 2004). FIII-1 and FIII-2 were the two most stable proteases towards a wide range of $\mathrm{pH}$ values in comparison to the others. The long-term preservation of the purified proteases at $4^{\circ} \mathrm{C}$ was experimentally investigated with two solvents, distilled water and sodium phosphate buffer $\mathrm{pH}$ 7.5. Sodium azide $(0.1 \% \mathrm{w} / \mathrm{v})$ was used as preservative. After 10 months, all fractions tended to be more stable in water (with only $10 \%$ activity loss) except for FIII-3, whose activity reduced to about $78 \%$ of the initial activity. In contrast, these enzymes were less stable in phosphate buffer since their activity decreased approximately $25-30 \%$ (data not shown).

\section{Inhibition of $P$. excavatus proteases}

PMSF is known as an effective inhibitor for serine proteases. As shown in Table 1, this compound could almost completely inhibit all protease fractions, causing $92-100 \%$ of activity loss. In contrast, EDTA had no inhibitory effect on any of the six fractions, suggesting that they were not metalloproteases, because such enzymes need a metal ion for activity. Only FIII-3 was inhibited to some extent by TPCK, which is a specific inhibitor for chymotrypsin-like serine proteases. The other reversible inhibitors such as SBTI, aprotinin, leupeptin and chymostatin caused different levels of inhibition of these proteases.

\section{Hydrolytic activity on different substrates}

All fractions were assayed for their hydrolytic ability towards different substrates including casein, fibrin, $\mathrm{BA} p \mathrm{NA}$, and BTpNA (Table 2). The last two are synthetic substrates specific for trypsin- and chymotrypsinlike proteases, respectively. None of these fractions showed hydrolytic activity towards BT $p$ NA, indicating that they probably do not belong to the chymotrypsinlike protease group. This result was in accordance with the inhibitory assay (Table 1) although FIII-3 was to some extent inhibited by TCPK, a specific inhibitor for chymotrypsin-like serine proteases. Only three fractions 


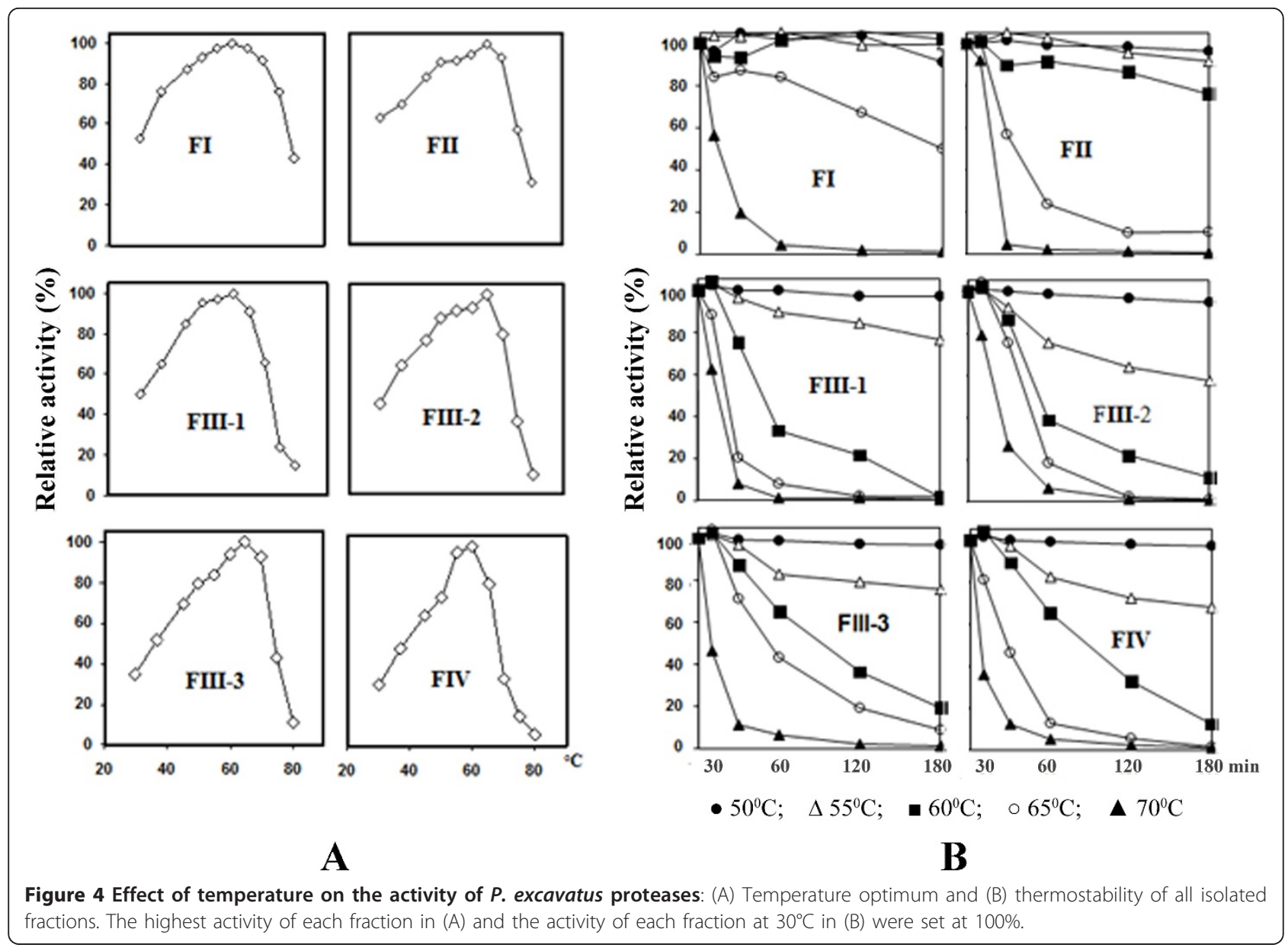

FIII-1, FIII-2 and FIV were able to show hydrolysis of $\mathrm{BA} p \mathrm{NA}$.

The caseinolytic activity was more or less the same for all fractions. Results from the fibrin plate assay, however, showed that all fractions had different levels of fibrinolytic activity. Three fractions FIII-3, FIII-2 and FI expressed the highest activity. Coagulated fibrin seemed not to be a specific substrate for FII since its hydrolysis towards fibrin was much smaller than those of the others.

The hydrolytic effect of these proteases towards fibrinogen monomers was also investigated. As visualized on the SDS-PAGE gel, all fractions could completely degrade the $A \alpha$ and $B \beta$ subunits of fibrinogen within 10 minutes, and FIII-1 and FIII-2 could even cleave off the $\gamma$ subunit. The hydrolytic ability of fraction FIII-2 was the highest since almost no protein bands were visible on the gel after 180 minutes (Figure 6). The hydrolytic activity was thus ranked as FIII-2 > FIII-1 > FI > FIV > FIII-3 > FII. The activity magnitude was more or less similar to the hydrolytic effect on intact fibrin in the fibrin-plate assay (Table 2).

\section{D-electrophoresis coupled MS/MS sequencing}

Each protease fraction was analyzed on 2D-PAGE gel for determination of their MW and pI. All fractions, except for FI and FIII-3, appeared as single spots, indicating that they were pure. The pI values of these fractions were denoted in Table 3, ranging from 4.3 to 5.2. Interestingly, they shared similar pI's with the proteases from E. fetida (Zhao et al. 2006). The presence of two protein with similar MW but different pI (5.0 and 5.2), was observed for FI, thus it might contain two isozymes. Fraction FIII-3 was hardly visible on the gel, probably due to the loss during sample preparation for 2D-electrophoresis. Therefore, the $\mathrm{pI}$ and MW of this fraction could not be determined.

Only the MS/MS spectra of FIII-1 and FIII-2 peptide fragments were obtained with good signal-to-noise ratios. The sequence alignments revealed that they shared considerable similarity ( $16.9 \%$ and $13.2 \%$, respectively) with the segments of fibrinolytic lumbrokinase isozyme C (EC 3.4.21) from L. rubellus and E. fetida (Figure 7). This enzyme is a serine protease with the length of 242 amino acid residues and a MW of $26 \mathrm{kDa}$. The two fractions 


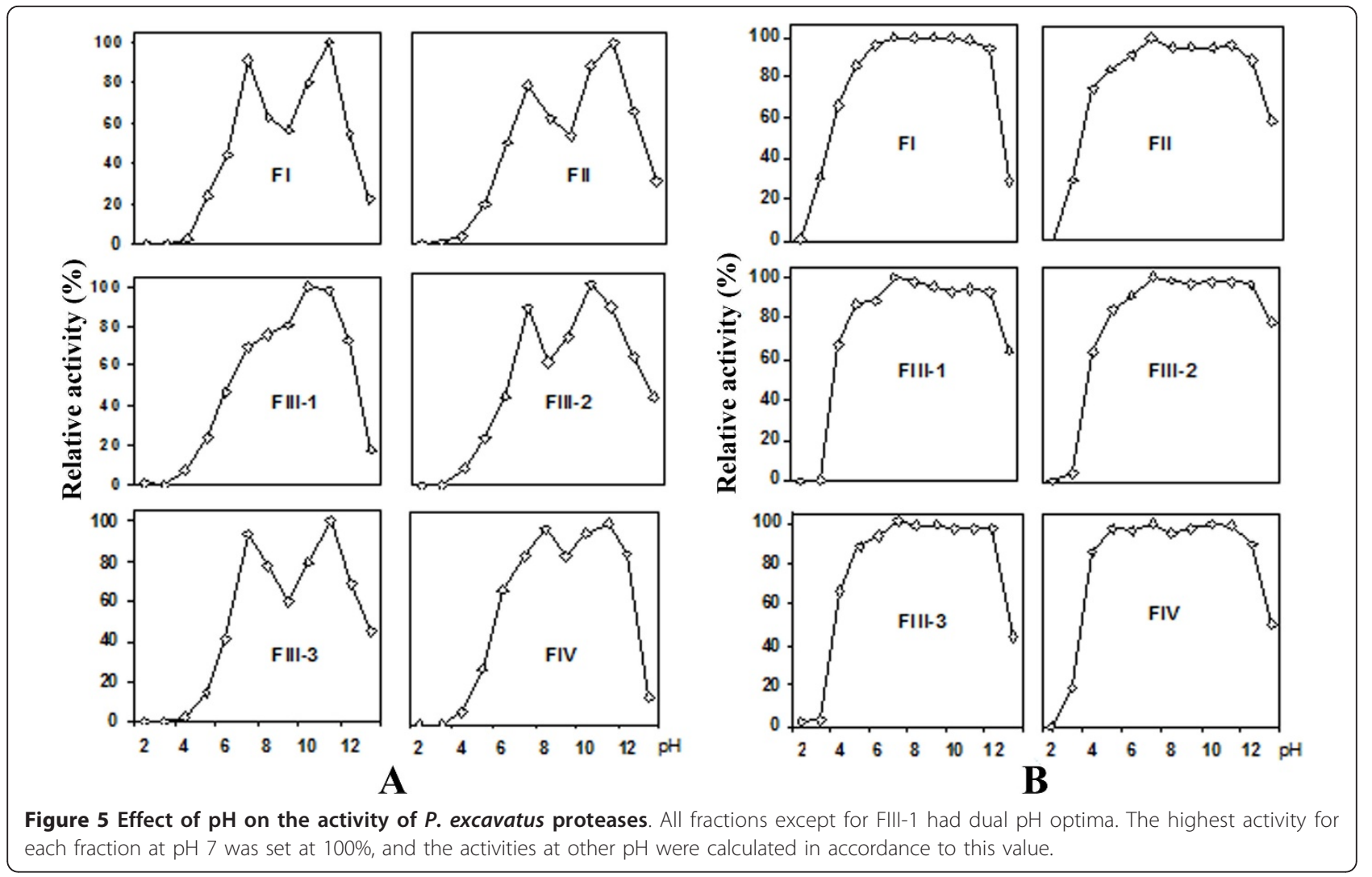

FIII-1 and FIII-2 also showed sequence similarity, but at a lower degree, with the serine proteases from mouse (Mus musculus). The spectra obtained from the other fractions gave no clear signals, so it was not possible to determine any of these peptide sequences.

\section{Discussion}

Initial autolysis is necessary for full activation of $P$. excavatus proteases

As we could see, the proteolytic activity towards casein increased and peaked through a 15-day autolysis. The

Table 1 Effect of different inhibitors on $P$. excavatus proteases.

\begin{tabular}{llcccccc}
\hline Inhibitors & Conc. (mM) & \multicolumn{6}{c}{ Relative activity (\%) } \\
\cline { 3 - 8 } & & FI & FII & FIII-1 & FIII-2 & FIII-3 & FIV \\
\hline Control & 100 & 100 & 100 & 100 & 100 & 100 \\
PMSF & 1 & 0 & 0 & 2 & 4 & 0 & 8 \\
TPCK & 0.1 & 100 & 100 & 96 & 100 & 76 & 100 \\
Aprotinin & 0.01 & 29 & 95 & 87 & 95 & 26 & 71 \\
Leupeptin & 0.1 & 0 & 100 & 98 & 100 & 0 & 73 \\
SBTI & 0.01 & 0 & 76 & 81 & 93 & 0 & 0 \\
EDTA & 1 & 100 & 100 & 100 & 100 & 100 & 100 \\
Chymostatin & 0.1 & 19 & 100 & 76 & 100 & 19 & 90 \\
Pepstatin & 1 & 100 & 58 & 60 & 86 & 83 & 75 \\
\hline
\end{tabular}

Relative activity was determined as percentage of the activity of enzyme without inhibitor (control) (results were rounded up to the integer) presence of sodium azide could inhibit the bacterial growth. The autolytic process could therefore trigger the release of proteases from the earthworm's tissues and exert a subsequent degradation of keratin and lipids, thus reducing the mixture's viscosity. The increase of proteolytic activity over time suggested that activation of these enzymes had occurred, probably through self-proteolysis that cleaved parts of the zymogens.

\section{Purification protocol for $P$. excavatus proteases}

The acetone precipitation of the $P$. excavatus lysate was more effective than ammonium sulfate (AS) precipitation because of more impurity removal, higher proteolytic activity recovery (data not shown) and less time consuming since subsequent dialysis is not necessary.

Table 2 Hydrolytic activity of $P$. excavatus proteases on different substrates

\begin{tabular}{ccccc}
\hline & \multicolumn{4}{c}{ Specific activity $\left(\mathbf{U}^{. m^{-1}}{ }^{-1}\right)$} \\
\hline Fractions & Fibrin & Casein & BApNA & BTpNA \\
\hline Fl & 602 & 1.8 & 0 & 0 \\
FII & 44 & 1 & 0 & 0 \\
FIII-1 & 393 & 1 & 0.1 & 0 \\
FIII-2 & 783 & 1 & 0.4 & 0 \\
FIII-3 & 831 & 1.2 & 0 & 0 \\
FIV & 296 & 0.9 & 2.2 & 0 \\
\hline
\end{tabular}




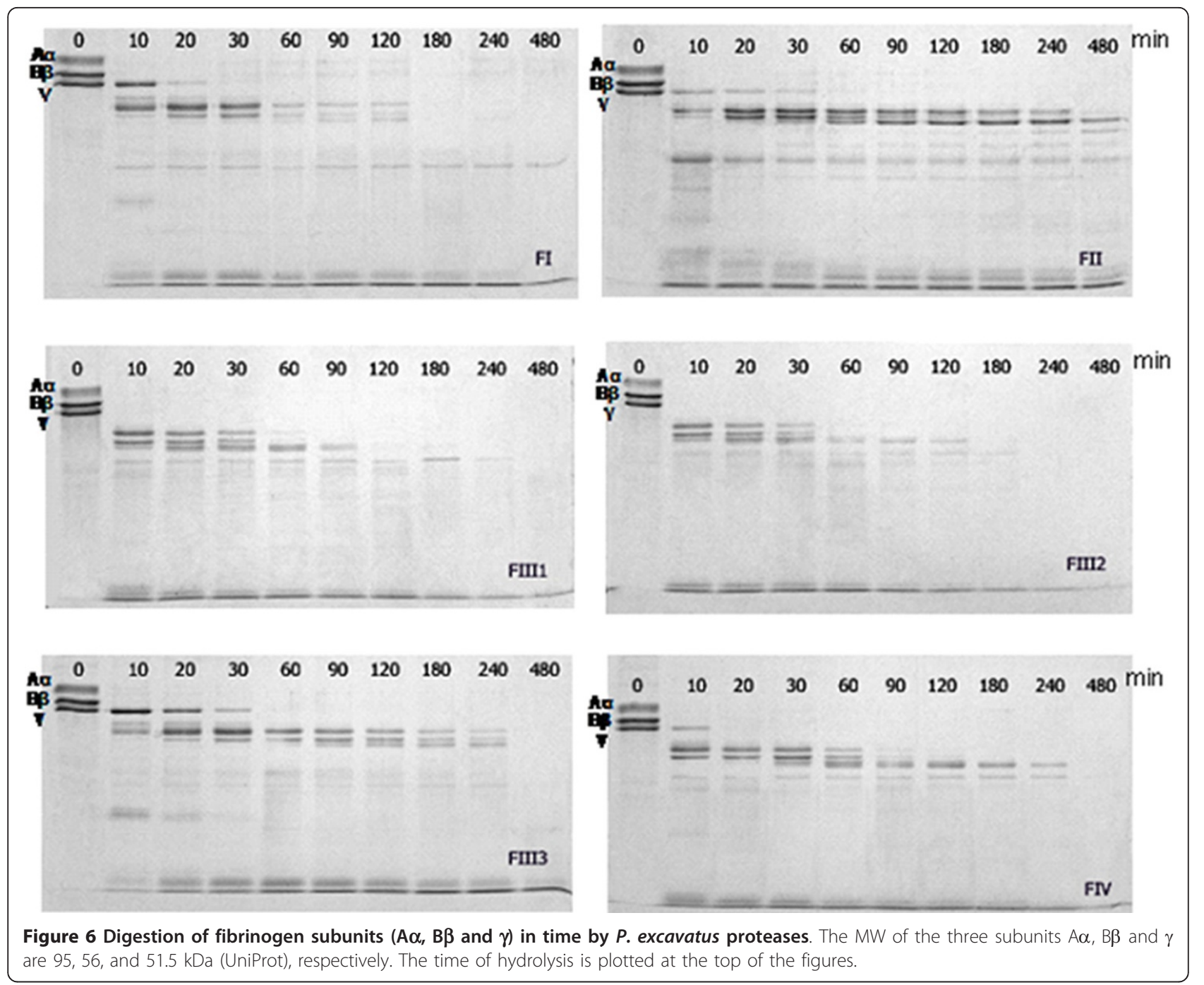

The presence of the $33 \mathrm{kDa}$ protein in faction FIII-3 could support the hypothesis of zymogen degradation mentioned earlier since it could be the zymogen of the $31 \mathrm{kDa}$ peptide, and its presence in the SEC fraction probably resulted from the incomplete initial autolysis.

Table 3 The values of $\mathrm{pl}$ and molecular weights (MW) of all P.excavatus proteases, except for FIII-3, determined by PDQuest ${ }^{\mathrm{TM}}$ 2-D Analysis Software (Bio-Rad, USA).

\begin{tabular}{lll}
\hline Fractions & pl & MW (kDa) \\
\hline FI (spot 1) & 5.0 & 27.5 \\
FI (spot 2) & 5.2 & 27.5 \\
FII & 4.3 & 29.0 \\
FIII-1 & 4.5 & 34.5 \\
FIII-2 & 4.3 & 33.5 \\
FIII-3 & not determined & \\
FIV & 4.5 & 34.0 \\
\hline
\end{tabular}

Similar results were reported in the study on L. rubellus earthworm (Cho et al. 2004) in which a 44 residues were cleaved off from a 283-residue-zymogen to release the fully active proteolytic enzyme. This hypothesis, however, requires further validation through sequencing of our FIII-3a and FIII-3b proteins.

Generally, the two-step chromatography of AEX and HIC was sufficient for the purification of FIII-1, FIII-2, and FII, since their SEC and SDS-PAGE profiles represented pure proteins. Fraction FI actually contained two isozymes with close $\mathrm{MW}$ and $\mathrm{pI}$, which could not be further separated. For FIII-3 and FIV, SEC was necessary to achieve the highest purity.

\section{P. excavatus proteases possess dual $\mathrm{pH}$ optima}

The dual $\mathrm{pH}$ optima has not been reported for the proteases from L. rubellus and E. fetida. However, this characteristic was found for the intestinal serine 


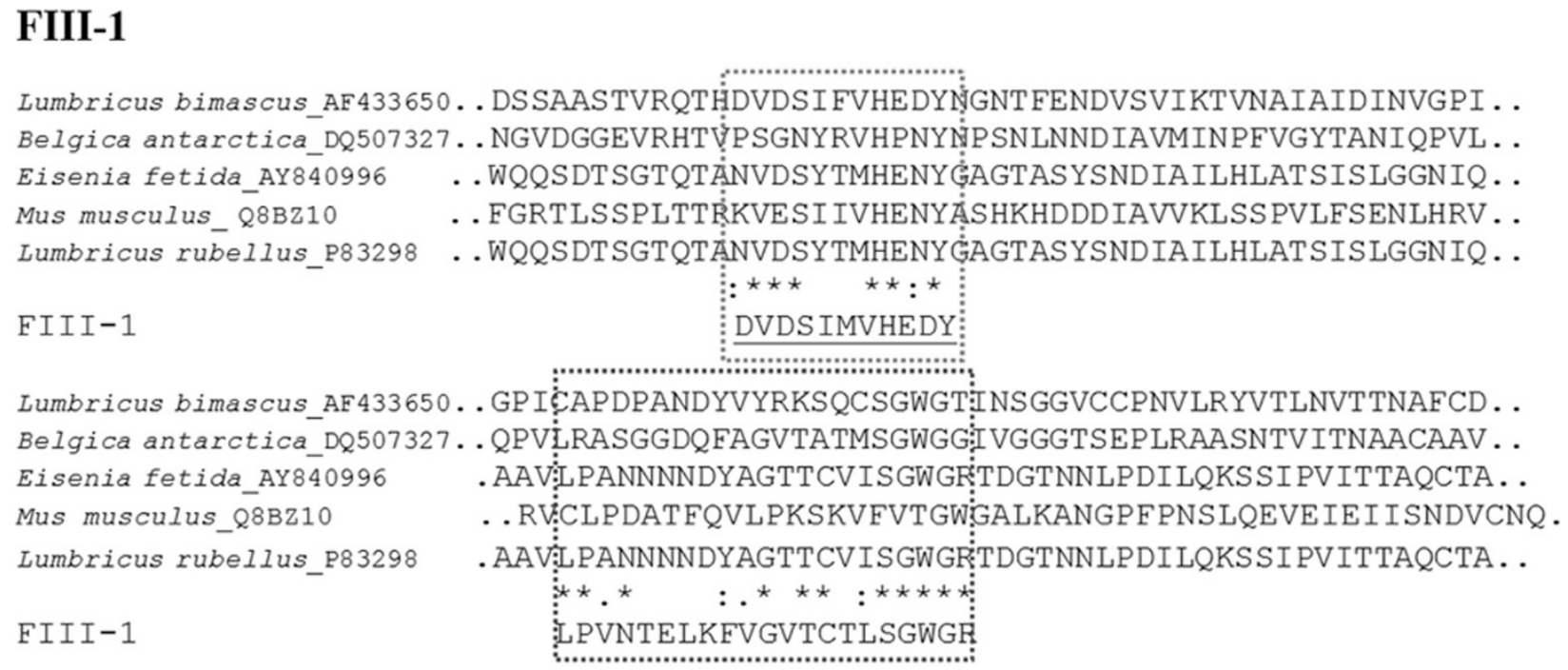

\section{FIII-2}

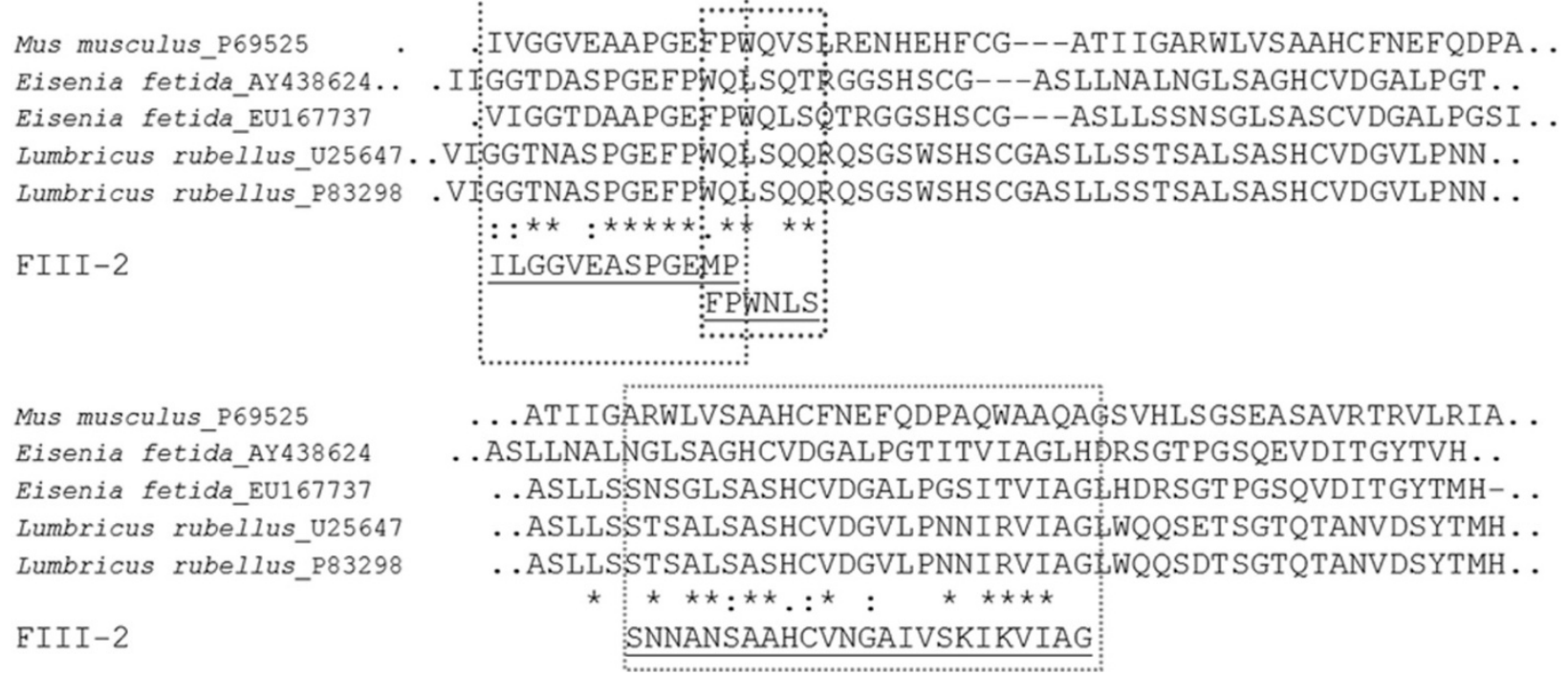

Figure 7 Sequence alignment of fragments obtained from MS/MS analyses of FIII-1 and FIII-2 from $P$. excavatus with lumbrokinase and its precursor from L. rubellus (sp:P83298 and U25647) and E. fetida (gpu:EU167737 and AY438624), with a serine protease from M. musculus (sp:P69525 and Q8BZ10) and B. antarctica (gpu:DQ507327). Symbols were defined as following: $\left(^{*}\right)$ for identical amino acids, (.) for redundant amino acids with similar 3D-structures, (:) for redundant amino acids with similar physicochemical properties. Significantly similar sequences were wrapped in dot-lined boxes.

protease of red flour beetle (Tribolium castaneum), whose optimal $\mathrm{pH}$ was determined to be at 4 and 8.5 (Oppert et al. 2003). (Choi et al. (1989)) studied the proteases from the parasitic protozoa Toxoplasma gondii and discovered that they catalyzed most effectively at $\mathrm{pH} 6$ and 8.5. Likewise, the dual pH optima characteristic has been observed in various hydrolases such as $\beta$-glucuronidase from human seminal plasma (Gupta and Singh 1983), Staphylococcus sp. xylanase
(Gupta et al. 2000), reptile lysozyme (Thammasirirak et al. 2006) and Rhizopus lipase (Upadhyay et al. 1989).

(Gupta et al. (2000)) hypothesized that the xylanase in their study might contain two distinct active sites that could perform catalysis at two distinct $\mathrm{pH}$ levels of 7.5 and 9.2, respectively, although no such enzyme has been reported before. In another study, the aspartate protease Plasmepsin I from Plasmodium falciparum was characterized, revealing the existence of two states of this 
protease as monomer and aggregated oligomer (Xiao et al. 2007). These two co-existing states resulted in the dual $\mathrm{pH}$ optima of the enzyme as determined experimentally. Since all protease fractions from $P$. excavatus in our study were completely inhibited by PMSF (Table 1 ), they would not harbor any active sites rather than the typical catalytic triad of serine proteases. Additionally, no aggregation was observed by SEC chromatography performed at $\mathrm{pH}$ 8.5. We therefore hypothesize that the $P$. excavatus proteases existed in both monomeric and aggregated oligomeric form in our assays; and the aggregation might be triggered at strong alkaline $\mathrm{pH}$, for instance $\mathrm{pH} 11$.

\section{Serine proteases}

The inhibitory effect of PMSF towards all fractions revealed that $P$. excavatus proteases are serine proteases, since PMSF is a specific irreversible inhibitor for this group of proteases (James 1978). FIII-3 was to some degree inhibited by TРCK, which is specific for chymotrysin-like protease (Table 1). However, it was not able to hydrolyze the chymotrypsin-like specific BTpNA substrate. Therefore, it was not possible to classify this protease. Two fractions FI and FII were also unambiguous since they had no activity towards both BApNA and $\mathrm{BT} p \mathrm{NA}$. In contrast, FIV was more likely a trypsin-like protease due to its specific hydrolysis of BApNA and specific inhibition by SBTI. Two fractions FIII-1 and FIII-2 displayed much lower hydrolytic effect on $\mathrm{BA} p \mathrm{NA}$ in comparison to FIV but were not inhibited by SBTI, thus it is still questionable if they were actually trypsin-like proteases.

On the other hand, the sequence alignment study revealed a considerable similarity between FIII-1 and FIII-2 fragments with the trypsin-like lumbrokinase fragments from L. rubellus and E. fetida. However, the sequence homology obtained in our study was expected to be higher because of the close evolutionary relationship between these earthworm species. Cho et al. reported extremely high conservation of the $\mathrm{N}$ terminal 20-22 residues between L. rubellus protease fractions (Cho et al. 2004). The sequence alignment within $P$. excavatus fractions was not conducted due to insufficient information from the MS/MS data. Therefore mass spectrometric analysis for these proteases should be further elaborated to obtain their full sequences.

\section{The isozymes expressed strong hydrolytic activity towards both fibrinogen and fibrin}

(Park et al. (2007)) discovered a protease from Flammulina velutipes that showed both fibrinolytic and fibrinogenolytic activity. This enzyme could perform hydrolyses without the presence of any activators, while human plasminogen is an inactive precursor and strictly requires tPA or urokinase for its conversion into fibrinolytic plasmin. In our experiment, all fractions except for FII displayed remarkable fibrinolysis, which was two to three times stronger than human plasmin (data not shown). They rapidly degraded the fibrinogen monomer as well. Therefore, the $P$. excavatus proteases would have a different catalytic mechanism towards these two substrates than human plasminogen. Moreover, each fraction experimentally displayed a distinct catalytic rate, thus probably having different kinetic parameters such as $K_{M}, V_{\text {max }}$, and $K_{\text {cat }}$.

\section{Applicability of $P$. excavatus proteases}

Pure proteins are generally less stable in water due to the absence of natural intracellular buffering and ionic conditions. Therefore, good storage conditions are required to maintain their biological activity. Nakajima et al. found that the protease fractions from Japanese L. rubellus could maintain approximately $80 \%$ of their activity after five years in $100 \mathrm{mM}$ Tris- $\mathrm{HCl}$ buffer at $\mathrm{pH} 8$ (Nakajima et al. 2000). Interestingly, our results revealed that water is more appropriate than phosphate buffer as a storage medium for $P$. excavatus proteases. In addition, the presence of plasminogen activators was declared to be unnecessary for the enzymes that could be able to hydrolyze both fibrinogen and fibrin (Park et al. 2007). These properties are favourable for convenient and cost-effective formulation of these enzymes. (Cho et al. (2004)) reported that all six protease fractions from L. rubellus had similar caseinolytic activity, only one of which exhibited remarkable fibrinolysis. This fraction was the first earthworm protease to be investigated for thrombosis therapy in Korea. Therefore, the proteases from $P$. excavatus characterised in the present study seem promising candidates for that purpose in Vietnam. Fraction FIII-2 is the most interesting fraction because of its strong fibrinolysis activity and high stability over long-term storage.

\section{Acknowledgements}

The authors are greatly thankful to Professor Les Copeland (Faculty of Agriculture, Food and Natural Resources - The University of Sydney, New South Wales, Australia) and Professor Kaeko Kamei (Department of Biomolecular Engineering, Kyoto Institute of Technology Matsugasaki, Sakyoku, Kyoto, Japan), who have kindly given the proof reading to the manuscript of this paper. The research was financially supported by the the Vietnamese Ministerial Research Project (B2007-16-56).

\section{Author details}

${ }^{1}$ College of Agriculture and Applied Biology, Can Tho University, Can Tho, Vietnam ${ }^{2}$ Faculty of Food Processing Technology, Can Tho University of Technology, Can Tho, Vietnam ${ }^{3}$ Biotechnology Research and Development Institute, Can Tho University, Can Tho, Vietnam ${ }^{4}$ Wageningen UR Food \& Bio-based Research, 6708 WG, Wageningen, The Netherlands

\section{Competing interests}

The authors declare that they have no competing interests. 
Received: 13 September 2011 Accepted: 30 September 2011 Published: 30 September 2011

\section{References}

Anson ML (1938) The Estimation of Pepsin, Trypsin, Papain, and Cathepsin with Hemoglobin. J Gen Physiol 22(1):79-89. doi:10.1085/jgp.22.1.79.

Arnesen H, Hoiseth A, Ly B (1982) Streptokinase of heparin in the treatment of deep vein thrombosis. Follow-up results of a prospective study. Acta Med Scand 211(1-2):65-8

Cho $H$, Choi ES, Lim HG, Lee HH (2004) Purification and characterization of six fibrinolytic serine-proteases from earthworm Lumbricus rubellus. J Biochem Mol Biol 37(2):199-205. doi:10.5483/BMBRep.2004.37.2.199.

Cho $\mathrm{IH}$, Choi ES, Lee HH (2004) Molecular cloning, sequencing, and expression of a fibrinolytic serine-protease gene from the earthworm Lumbricus rubellus. J Biochem Mol Biol 37(5):574-81. doi:10.5483/BMBRep.2004.37.5.574.

Choi WY, Nam HW, Youn JH (1989) Characterization of proteases of Toxoplasma gondii. Kisaengchunghak Chapchi 27(3):161-70

Choi HS, Sa YS (2001) Fibrinolytic and antithrombotic protease from Spirodela polyrhiza. Biosci Biotechnol Biochem 65(4):781-6. doi:10.1271/bbb.65.781.

Dong GQ, Yuan XL, Shan YJ, Zhao ZH, Chen JP, Cong YW (2004) Molecular cloning and characterization of CDNA encoding fibrinolytic enzyme-3 from earthworm Eisenia foetida. Acta Biochim Biophys Sin (Shanghai) 36(4):303-8. doi:10.1093/abbs/36.4.303.

Einhaupl KM, Villringer A, Meister W, Mehraein S, Garner C, Pellkofer M, Haberl RL, Pfister HW, Schmiedek P (1991) Heparin treatment in sinus venous thrombosis. Lancet 338(8767):597-600. doi:10.1016/0140-6736(91)90607-Q.

Furie B, Furie BC (2008) Mechanisms of thrombus formation. N Engl J Med 359(9):938-49. doi:10.1056/NEJMra0801082.

Ge T, Sun ZJ, Fu SH, Liang GD (2005) Cloning of thrombolytic enzyme (lumbrokinase) from earthworm and its expression in the yeast Pichia pastoris. Protein Expr Purif 42(1):20-8. doi:10.1016/j.pep.2005.04.005.

Grundy SM, Pasternak R, Greenland P, Smith S, Fuster V (1999) Assessment of Cardiovascular Risk by Use of Multiple-Risk-Factor Assessment Equations. Circulation 100:1481-1492

Gupta S, Bhushan B, Hoondal GS (2000) Isolation, purification and characterization of xylanasefrom Staphylococcus sp. SG-13 and its application in biobleaching of kraft pulp. J Appl Microbiol 88(2):325-34.

Gupta GS, Singh GP (1983) Isolation and characterization of the major form of beta-glucuronidase from human seminal plasma. Biochim Biophys Acta 748(3):398-404. doi:10.1016/0167-4838(83)90185-1.

Hames BD (1998) Gel electrophoresis of proteins. A practical approach, 3rd edn. Oxford University.

James GT (1978) Inactivation of the protease inhibitor phenylmethylsulfonyl fluoride in buffers. Anal Biochem 86(2):574-9. doi:10.1016/0003-2697(78) 90784-4.

Kakkar W, Flanc C, Howe CT, O'Shea M, Flute PT (1969) Treatment of deep vein thrombosis. A trial of heparin, streptokinase, and arvin. Br Med J , 5647: 806-10.

Kannel WB, Wolf PA, Castelli WP, D'Agostino RB (1987) Fibrinogen and risk of cardiovascular disease. The Framingham Study. JAMA 258(9):1183-1186. doi:10.1001/jama.258.9.1183.

Lowry OH, Rosenberg WJ, Farr AL, Randall RJ (1951) Quantization of protein using Folin-Ciocalteau reagent. J Biol Chem 193:265-275.

Marder VJ, Soulen RL, Atichartakarn V, Budzynski AZ, Parulekar S, Kim JR, Edward N, Zahavi J, Algazy KM (1977) Quantitative venographic assessment of deep vein thrombosis in the evaluation of streptokinase and heparin therapy. J Lab Clin Med 89(5):1018-29.

Mehraein S, Schmidtke K, Villringer A, Valdueza JM, Masuhr F (2003) Heparin treatment in cerebral sinus and venous thrombosis: patients at risk of fatal outcome. Cerebrovasc Dis 15(1-2):17-21. doi:10.1159/000067117.

Mihara H, Sumi H, Yoneta T, Mizumoto H, Ikeda R, Seiki M, Maruyama M (1991) A novel fibrinolytic enzyme extracted from the earthworm, Lumbricus rubellus. Jpn J Physiol 41(3):461-72. doi:10.2170/jjphysiol.41.461.

Mosesson MW (2005) Fibrinogen and fibrin structure and functions. J Thromb Haemost 3(8):1894-904. doi:10.1111/j.1538-7836.2005.01365.x.

Mosesson MW, Siebenlist KR, Meh DA (2001) The structure and biological features of fibrinogen and fibrin. Ann N Y Acad Sci 936:11-30.

Nakajima N, Mihara H, Sumi H (1993) Characterization of potent fibrinolytic enzymes in earthworm, Lumbricus rubellus. Biosci Biotechnol Biochem 57(10):1726-30. doi:10.1271/bbb.57.1726.
Nakajima N, Sugimoto M, Ishihara K (2000) Stable earthworm serine proteases: application of the protease function and usefulness of the earthworm autolysate. J Biosci Bioeng 90(2):174-9.

Oppert B, Morgan TD, Hartzer K, Lenarcic B, Galesa K, Brzin J, Turk V, Yoza K, Ohtsubo K, Kramer KJ (2003) Effects of proteinase inhibitors on digestive proteinases and growth of the red flour beetle, Tribolium castaneum (Herbst) (Coleoptera: Tenebrionidae). Comp Biochem Physiol C Toxicol Pharmacol 134(4):481-90. doi:10.1016/S1532-0456(03)00042-5.

Park SE, Li MH, Kim JS, Sapkota K, Kim JE, Choi BS, Yoon YH, Lee JC, Lee HH, Kim CS, others (2007) Purification and characterization of a fibrinolytic protease from a culture supernatant of Flammulina velutipes mycelia. Biosci Biotechnol Biochem 71(9):2214-22. doi:10.1271/bbb.70193.

Stam J, de Bruijn S, deVeber G (2003) Anticoagulation for cerebral sinus thrombosis. Stroke 34(4):1054-5. doi:10.1161/01.STR.0000062344.87396.72.

Sugimoto M, Nakajima N (2001) Molecular cloning, sequencing, and expression of CDNA encoding serine protease with fibrinolytic activity from earthworm. Biosci Biotechnol Biochem 65(7):1575-80. doi:10.1271/bbb.65.1575.

Tang Y, Liang D, Jiang T, Zhang J, Gui L, Chang W (2002) Crystal structure of earthworm fibrinolytic enzyme component a: revealing the structural determinants of its dual fibrinolytic activity. J Mol Biol 321(1):57-68. doi:10.1016/S0022-2836(02)00559-4.

Thammasirirak S, Ponkham P, Preecharram S, Khanchanuan R, Phonyothee $P$, Daduang S, Srisomsap C, Araki T, Svasti J (2006) Purification, characterization and comparison of reptile lysozymes. Comp Biochem Physiol C Toxicol Pharmacol 143(2):209-17. doi:10.1016/j.cbpc.2006.02.004.

Upadhyay CM, Nehete PN, Rothari RM (1989) A lipase preparation with dual pH optima, wide temperature optima and broad substrate specificity for multiple applications. Biotechnology Letters 11(11):793-796. doi:10.1007/ BF01026099.

Wang F, Wang C, Li M, Zhang JP, Gui LL, An XM, Chang WR (2005) Crystal structure of earthworm fibrinolytic enzyme component B: a novel, glycosylated two-chained trypsin. J Mol Biol 348(3):671-85. doi:10.1016/j. jmb.2005.02.055.

Xiao H, Tanaka T, Ogawa M, Yada RY (2007) Expression and enzymatic characterization of the soluble recombinant plasmepsin I from Plasmodium falciparum. Protein Eng Des Sel 20(12):625-33. doi:10.1093/protein/gzm066.

Xu ZR, Yang YM, Gui QF, Zhang LN, Hu L (2010) Expression, purification, and characterization of recombinant lumbrokinase PI239 in Escherichia coli. Protein Expr Purif 69(2):198-203. doi:10.1016/j.pep.2009.08.013.

Yang JS, Ru BG (1997) Purification and characterization of an SDS-activated fibrinolytic enzyme from Eisenia fetida. Comp Biochem Physiol B Biochem Mol Biol 118(3):623-31. doi:10.1016/S0305-0491(97)00223-X.

Zhao XY, Liu ZM, Jing TY, Wu JX, Zhao ZY (2006) A component of earthworm fibrinolytic enzyme having higher thrombolytic activity than total components in vivo. Yao Xue Xue Bao 41(11):1068-73.

doi:10.1186/2191-0855-1-26

Cite this article as: Phan et al:: Purification and characterization of novel fibrinolytic proteases as potential antithrombotic agents from earthworm Perionyx excavatus. AMB Express 2011 1:26.

\section{Submit your manuscript to a SpringerOpen ${ }^{\odot}$ journal and benefit from:}

- Convenient online submission

- Rigorous peer review

- Immediate publication on acceptance

- Open access: articles freely available online

- High visibility within the field

- Retaining the copyright to your article

Submit your next manuscript at $\boldsymbol{s p r i n g e r o p e n . c o m ~}$ 